\title{
After all, how is the Zika virus transmitted?
}

\begin{abstract}
Zika (ZIKV) has spread rapidly throughout the world, causing serious epidemics. But, before the recent outbreak in Brazil, little was known about the virus or its mode of transmission. After ZIKV and microcephaly were associated in the Brazilian Northeast, virus spread caused international repercussions, generating the need to investigate other possibilities of transmission. Therefore, our objective was to identify the possible ways of ZIKV transmission described in the literature. A review of the published literature was carried out on the following databases: Scielo, Pubmed and Lilacs, related to ZIKV, from 1950 to 2006, and from 2006 to 2017. Only 46 publications were found in the period between 1950 to 2006. However, after the epidemics in the Yap Islands and in French Polynesia, more than 2000 publications were generated. The most common reported mode of transmission was the infected vector, especially those of the genus Aedes - $A$. aegypti was the most frequently cited. Some other possible vectors were cited as well, such as Culex spp. However, studies suggest that this vector would not have the competence to transmit the ZIKV, which warrants further study. Other forms of documented transmission were through sexual intercourse, saliva, amniotic fluid, urine, semen, breast milk, blood transfusion and laboratory exposure. Given the great transmission potential of the ZIKV, its control has become a major challenge to global health. All these modes of transmission need to be further investigated to determine the relative weight of each one in any given epidemic.
\end{abstract}

Keywords: Zika virus, Aedes aegypt, Culex, transmission, microcephaly
Volume 5 Issue 6 - 2017

\author{
Francisca Kalline de Almeida Barreto,' \\ Rhaquel de Morais Alves Barbosa Oliveira,' \\ Caroline Mary Gurgel Dias Florencio,' \\ lleana Pitombeira Gomes, ' Carlos Henrique \\ Alencar, ${ }^{2}$ Luciano Pamplona de Goes \\ Cavalcanti ${ }^{2}$ \\ 'Post-Graduate student in Public Health, Federal University of \\ Ceara \\ ${ }^{2}$ Departamento de Saude Comunitaria, Federal University of \\ Ceara (UFC), Brazil
}

Correspondence: Luciano Pamplona de Goes Cavalcanti, Departamento de Saude Comunitaria, Faculdade de Medicina, Universidade Federal do Ceara, Fortaleza, Ceara, Brasil, Tel 55 85 999878969, Email pamplona.luciano@gmail.com

Received: August 28, 2017 | Published: October 23, 2017
Abbreviations: SZC, congenital zika syndrome; ZIKV, zika virus; WHO, word health organization

\section{Introduction}

Zika (ZIKV) belongs to the Flavivirus genus of the Flaviviridae family and was isolated in 1947 in a monkey of the genus Rhesus, from Zika Forest, Uganda. In the following year the ZIKV was isolated in a mosquito of the species Aedes africanus, ${ }^{1}$ and studies have demonstrated the vector competence of Aedes spp. mosquitoes as possible vectors for this virus. ${ }^{2,3}$ The first reported human infection occurred in $1954^{4}$ and only 14 cases of the disease had been reported worldwide by $2006 .^{5}$

\section{Discussion}

After almost 60 years since it was first detected, only a handful of studies were directed at Zika fever or factors related to the virus transmission. Only 46 publications were found from 1950 to 2006 . $^{6}$. With the Yap Islands and French Polynesia epidemics in 2007 and 2013, respectively, the virus sparked interest once again. ${ }^{5,78}$. Yet, it was only after an epidemic spread throughout the Brazilian Northeast, with the suspicion of a possible association with microcephaly, that publications rose dramatically. ${ }^{9-13}$

After this event, the virus spread to other countries. By February 2016, the disease was declared an International Public Health Emergency by the World Health Organization (WHO). ${ }^{11,14-17}$ By November 2016,ZIKV cases were reported in 48 different countries, ${ }^{17,18}$ catching the attention of researchers around the world. Until 2015, it was believed that the transmission to humans occurred only through the bite of infected vectors, especially Aedes aegypti mosquitoes. ${ }^{5}$ However, due to the large number of people affected by the disease in a short time, questions were raised regarding other possible forms of ZIKV transmission. So, after all, how is the Zika virus transmitted?
New research has provided some answers, but has also raised some doubts.

Aedes aegypti has always been associated with Zika, and several studies support its competence under laboratory conditions. ${ }^{1,3,18-23}$ Naturally infected Aedes aegypti have beencaptured in the field..$^{24}$ This led to the initial hypothesis of a single transmitting species. There is also evidence of other mosquitoes in the Aedes genus with vectorial competence to transmit ZIKV. ${ }^{5,20,23,25-32}$ Due to its great abundance and antrophilia, Culex spp. was suspected as an alternative ZIKV vector. Culex thrives close to epidemic areas, especially in low-income districts where microcephaly cases were higher. ${ }^{33}$ There are records of some naturally infected species. ${ }^{26}$ Culex spp. are susceptible to ZIKV infection and able to effectively transmit ZIKV. ${ }^{34,35}$ On the other hand, other studies suggest that this vector may not have competence to transmit ZIKV..$^{18,32,33,35-37}$ Thus, this subject warrants further analysis, along with field experiments in areas of active ZIKV transmission.

With the rapidly spread of this epidemic throughout the world, other possibilities of transmission have been raised, and there are already important records of possible transmission through sexual intercourse, saliva, amniotic fluid, urine, semen, breast milk, blood transfusion and laboratory exposure. , $^{7,11,11,38-47}$

\section{Conclusion}

With the discovery of the association between microcephaly and ZIKV, and the emergence of a new syndrome (Congenital Zika Syndrome), there have been many advances in this field. In view of the large potential transmission of ZIKV and its clear association with cases of (CZS), its control has become a major challenge for global health, even in regions without Aedes mosquitoes. All possibilities of transmission need to be rigorously investigated to determine the relative weight of each in an epidemic process. It is necessary to understand these different scenarios (with and without the presence 
of Aedes aegypti) to determine the potential for dissemination of CZS cases worldwide. In addition, it is necessary to understand why the epidemic of CZS did not take on the worldwide proportion that was speculated.

\section{Acknowledgements}

None.

\section{Conflicts of interest}

There are no conflicts of interest on the part of the authors of the article.

\section{Funding}

None.

\section{References}

1. Dick GW, Kitchen SF, Haddow AJ. Zika virus. I. Isolations and serological specificity. Trans R Soc Trop Med Hyg. 1952;46(5):509-520.

2. Boorman JP, Porterfield JS. A simple technique for infection of mosquitoes with viruses; transmission of Zika virus. Trans $R$ Soc Trop Med Hyg. 1956;50(3):238-242.

3. Marchette NJ, Garcia R, Rudnick A. Isolation of Zika virus from Aedes aegypti mosquitoes in Malaysia. Am J Trop Med Hyg. 1969;18(3):411415.

4. Macnamara FN. Zika virus: a report on three cases of human infection during an epidemic of jaundice in Nigeria. Trans $R$ Soc Trop Med Hyg. 1954;48(2):139-145.

5. Duffy MR, Chen TH, Hancock WT, et al. Zika virus outbreak on Yap Island, Federated States of Micronesia. $N$ Engl J Med. 2009;360(24):2536-2543.

6. Posen HJ, Keystone JS, Gubbay JB, et al. Epidemiology of Zika virus, 1947-2007. BMJ Glob Health. 2016;1(2):e000087.

7. Musso D, Nhan T, Robin E, et al. Potential for Zika virus transmission through blood transfusion demonstrated during an outbreak in French Polynesia, November 2013 to February 2014. Euro Surveill. 2014;19(14):20761

8. Tognarelli J, Ulloa S, Villagra E, et al. A report on the outbreak of Zika virus on Easter Island, South Pacific, 2014. Arch Virol. 2016;161(3):665668.

9. Campos GS, Bandeira AC, Sardi SI. Zika Virus Outbreak, Bahia, Brazil. Emerg Infect Dis. 2015;21(10):1885-1886.

10. Zanluca C, Melo VC, Mosimann AL, et al. First report of autochthonous transmission of Zika virus in Brazil. Mem Inst Oswaldo Cruz. 2015;110(4):569-572.

11. Oliveira Melo AS, Malinger G, Ximenes R, et al. Zika virus intrauterine infection causes fetal brain abnormality and microcephaly:tip of the iceberg? Ultrasound Obstet Gynecol. 2016;47(1):6-7.

12. Rasmussen SA, Jamieson DJ, Honein MA, et al. Zika Virus and Birth Defects-Reviewing the Evidence for Causality. $N$ Engl J Med. 2016;374(20):1981-1987.

13. Brasil P, Calvet GA, Siqueira AM, et al. Zika Virus Outbreak in Rio de Janeiro, Brazil:Clinical Characterization, Epidemiological and Virological Aspects. PLoSNegl Trop Dis. 2016;10(4):e0004636.

14. Mlakar J, Korva M, Tul N, et al. Zika Virus Associated with Microcephaly. N Engl J Med. 2016;374(10):951-958.

15. Garcez PP, Loiola EC, Madeiro da Costa R, et al. Zika virus impairs growth in human neurospheres and brain organoids. Science. 2016;352(6287):816-818.

16. Tang H, Hammack C, Ogden SC, et al. Zika Virus Infects Human Cortical Neural Progenitors and Attenuates Their Growth. Cell stem cell. 2016;18(5):587-590.

17. http://ais.paho.org/phip/viz/ed_zika_countrymap.asp

18. Weger-Lucarelli J, Ruckert C, Chotiwan N, et al. Vector Competence of American Mosquitoes for Three Strains of Zika Virus. PLoS Negl Trop Dis. 2016;10(10):e0005101.

19. Li MI, Wong PS, Ng LC, et al. Oral susceptibility of Singapore Aedes (Stegomyia) aegypti (Linnaeus) to Zika virus. PLoS Negl Trop Dis. 2012;6(8):e1792.

20. Chouin-Carneiro T, Vega-Rua A, Vazeille M, et al. Differential Susceptibilities of Aedes aegypti and Aedes albopictus from the Americas to Zika Virus. PLoS Negl Trop Dis. 2016;10(3):e0004543.

21. Hall-Mendelin S, Pyke AT, Moore PR, et al. Assessment of Local Mosquito Species Incriminates Aedes aegypti as the Potential Vector of Zika Virus in Australia. PLoS Negl Trop Dis. 2016;10(9):e004959.

22. Richard V, Paoaafaite T, Cao-Lormeau VM. Vector Competence of French Polynesian Aedes aegypti and Aedes polynesiensis for Zika Virus. PLoS Negl Trop Dis. 2016;10(9):e0005024.

23. Thangamani S, Huang J, Hart CE, et al. Vertical Transmission of Zika Virus in Aedes aegypti Mosquitoes. Am J Trop Med Hyg. 2016;95(5):1169-1173.

24. Guerbois M, Fernandez-Salas I, Azar SR, et al. Outbreak of Zika Virus Infection, Chiapas State, Mexico, 2015, and First Confirmed Transmission by Aedes aegypti Mosquitoes in the Americas. J Infect Dis. 2016;214(9):1349-1356.

25. Haddow AJ, Williams MC, Woodall JP, et al. Twelve Isolations of Zika Virus from Aedes (Stegomyia) Africanus (Theobald) Taken in and above a Uganda Forest. Bull World Health Organ. 1964;31:57-69.

26. Diallo D, Sall AA, Diagne CT, et al. Zika virus emergence in mosquitoes in southeastern Senegal, 2011. PloS one. 2014;9(10):e109442.

27. Wong PS, Li MZ, Chong CS, et al. Aedes (Stegomyia) albopictus (Skuse):a potential vector of Zika virus in Singapore. PLoS Negl Trop Dis. 2013;7(8):e2348.

28. Grard G, Caron M, Mombo IM, et al. Zika virus in Gabon (Central Africa) -2007:a new threat from Aedes albopictus? PLoS Negl Trop Dis. 2014;8(2):e2681.

29. Ledermann JP, Guillaumot L, Yug L, et al. Aedes hensilli as a potential vector of Chikungunya and Zika viruses. PLoS Negl Trop Dis. 2014;8(10):e3188.

30. Diagne CT, Diallo D, Faye O, et al. Potential of selected Senegalese Aedes spp. mosquitoes (Diptera:Culicidae) to transmit Zika virus. BMC Infect Dis. 2015;15:492.

31. Di Luca M, Severini F, Toma L, et al. Experimental studies of susceptibility of Italian Aedes albopictus to Zika virus. Euro Surveill. 2016;21(18).

32. Aliota MT, Peinado SA, Osorio JE, et al. Culex pipiens and Aedes triseriatus Mosquito Susceptibility to Zika Virus. Emerg Infect Dis. 2016;22(10):1857-1859.

33. Fernandes RS, Campos SS, Ribeiro PS, et al. Culex quinquefasciatus from areas with the highest incidence of microcephaly associated with Zika virus infections in the Northeast Region of Brazil are refractory to the virus. Mem Inst Oswaldo Cruz. 2017;112(8):577-579.

34. Guo XX, Li CX, Deng YQ, et al. Culex pipiens quinquefasciatus:a potential vector to transmit Zika virus. Emerg Microbes Infect. 2016;5(9):e102. 
35. Guedes DRD, Paiva MHS, Donato MMA, et al. Zika virus replication in the mosquito Culex quinquefasciatus in Brazil. Emerg Microbes Infect. 2017;6(8):e69.

36. Fernandes RS, Campos SS, Ferreira-de-Brito A, et al. Culex quinquefasciatus from Rio de Janeiro Is Not Competent to Transmit the Local Zika Virus. PLoS Negl Trop Dis. 2016;10(9):e0004993.

37. Boccolini D, Toma L, Di Luca M, et al. Experimental investigation of the susceptibility of Italian Culex pipiens mosquitoes to Zika virus infection. Euro Surveill. 2016;21(35).

38. Vasilakis N, Weaver SC. Flavivirus transmission focusing on Zika. Curr Opin Virol. 2016;22:30-35.

39. Musso D, Roche C, Robin E, et al. Potential sexual transmission of Zika virus. Emerg Infect Dis. 2015;21(2):359-361.

40. Gourinat AC, Connor O, Calvez E, et al. Detection of Zika virus in urine. Emerg Infect Dis. 2015;21(1):84-86.

41. Besnard M, Lastere S, Teissier A, et al. Evidence of perinatal transmission of Zika virus, French Polynesia, December 2013 and February 2014. Euro Surveill. 2014;19(13).

42. Atkinson B, Hearn P, Afrough B, et al. Detection of Zika Virus in Semen. Emerg Infect Dis. 2016;22(5):940.
43. Barreiro P. Evolving RNA Virus Pandemics:HIV, HCV, Ebola, Dengue, Chikunguya, and now Zika! AIDS rev. 2016;18(1):54-55.

44. Davidson A, Slavinski S, Komoto K, et al. Suspected Female-to-Male Sexual Transmission of Zika Virus - New York City, 2016. MMWR Morb Mortal Wkly Rep. 2016;65(28):716-717.

45. Foy BD, Kobylinski KC, Chilson Foy JL, et al. Probable non-vectorborne transmission of Zika virus, Colorado, USA. Emerg Infect Dis. 2011;17(5):880-882.

46. Frank C, Cadar D, Schlaphof A, et al. Sexual transmission of Zika virus in Germany, April 2016. Euro surveill. 2016;21(23).

47. Hills SL, Russell K, Hennessey M, et al. Transmission of Zika Virus Through Sexual Contact with Travelers to Areas of Ongoing Transmission - Continental United States, 2016. MMWR Morb Mortal Wkly Rep. 2016;65(8):215-216.

48. Oster AM, Brooks JT, Stryker JE, et al. Interim Guidelines for Prevention of Sexual Transmission of Zika Virus - United States, 2016. MMWR Morb Mortal Wkly Rep. 2016;65(5):120-121.

49. Staples JE, Dziuban EJ, Fischer M, et al. Interim Guidelines for the Evaluation and Testing of Infants with Possible Congenital Zika Virus Infection - United States, 2016. MMWR Morb Mortal Wkly Rep. 2016;65(3):63-67. 